\title{
Animal Rescue as Civil Disobedience
}

\author{
Tony Milligan ${ }^{1}$
}

(C) The Author(s) 2017. This article is an open access publication

\begin{abstract}
Apparently illegal cases of animal rescue can be either open or covert: 'open rescue' is associated with organizations such as Animal Liberation Victoria and Animal Liberation New South Wales; 'covert rescue' is associated with the Animal Liberation Front. While the former seems to qualify non-controversially as civil disobedience I argue that (irrespective of other considerations such as effectiveness or advisability) at least some instances of the latter could also qualify as civil disobedience just so long as various norms of civility (e.g. norms concerning recognition of others, the avoidance of violence and threats) are satisfied. The case for such a move is defended against objections that covertness is (1) inherently suspect; (2) a failure to accept responsibility; and (3) inconsistent with civil disobedience as a form of communication. Against such objections, the paper emphasizes the importance of respecting the open texture of the concept of civil disobedience if it is to be of continuing relevance against the backdrop of changing forms of non-violent dissent.
\end{abstract}

Keywords Civil disobedience · Violence - Communication · Rawls · Covert rescue $\cdot$ Open rescue

\section{Animal Rescue}

I want to argue that covert acts of animal rescue may (under some circumstances) qualify as instances of civil disobedience. This is not necessarily a justification of these actions or of their strategic wisdom as part of any broader approach towards securing animal rights. It is, however, a defence of the view that even if unjustified

Tony Milligan

Anthony.milligan@kcl.ac.uk

1 Department of Theology and Religious Studies, King's College London, Virginia Woolf Building, 22 Kingsway, London WC2B 6LE, UK 
the acts in question still have a special standing. I will also take it that (irrespective of whatever else we want to say about the concept of civil disobedience) a claim of special standing is what is brought into play when we refer to 'civil disobedience' by contrast with 'direct action' or by contrast with various forms of political violence. (A point explained in more detail below.) By 'animal rescue' I have in mind actions which involve the following:

(1) Removal of one or more animals from a situation of harm that has been deliberately brought about by humans.

(2) Removal for the sake of the animal itself. (Although perhaps not only for the sake of the animal.)

(3) Illegality, or at least the appearance of illegality in the form of trespass, breaking and entering, and theft. (With the animals in question being regarded as someone else's property.)

The third clause focuses attention upon the appearance of illegality in order to mark a contrast with the licensed (and legal) rescue operations of special animal welfare bodies such as the RSPCA. This paper focuses instead upon actions performed by animal rights activists when acting specifically as animal rights activists. Whether or not the actions in question turn out to be illegal on some best account of what the law is can be a matter for debate, although there is perhaps a default presupposition of their illegality.

The two dominant forms of animal rescue, in this militant and challenging sense, are covert rescue (with identity concealment) and open rescue (with identity disclosure on the part of at least some of those involved). Covert rescue, in its systematically organized form, has been practised since at least the 1970s and is strongly associated with the Animal Liberation Front (ALF). ${ }^{1}$ Sporadic instances of open rescue also date back to (at least) the later 1970s, but in its systematic and regular form this kind of rescue dates only to the 1990s. Specifically, it dates back to a sustained campaign of animal rescue initiated in 1993 and spearheaded by various Australian animal rights organizations, the best known of which is Animal Liberation Victoria (ALV). ${ }^{2}$ Open rescue is still practised in Australia and it is also practised by animal rights groups in Europe and in the US but more sporadically and with far less media coverage. ${ }^{3}$

Open rescue is quasi-respectable, and has been linked (by activists) with Gandhi's concept of satyagraha which, for simplicity, we may understand as the non-violent struggle for justice and truth. ${ }^{4}$ (An implication of this is that satyagraha for a bad cause would not be possible.) Covert rescue has a less favourable image. It has been associated (at least in the US) with domestic terrorism and attempts have been made to cluster legal responses to covert rescue together with responses to

\footnotetext{
${ }^{1}$ Newkirk (2000), Mann (2009).

${ }^{2}$ Mark (2003), Hawthorn (2010), O'Sullivan (2011), pp. 92-93.

${ }^{3}$ Milligan (2013), chapter 11.

${ }^{4}$ For civil disobedience as a branch of satyagraha see Gandhi (1996, pp. 50-57). For the association between satyagraha and related forms of eco-activism see Naess (1974). For the association with open animal rescue, see Milligan (2017).
} 
Islamic extremism. ${ }^{5}$ While this may make the distinction between open and covert appear to be a rigid dichotomy, it nonetheless holds only up to a point. An open rescue on the ALV model will typically involve some covert information gathering prior to the (similarly covert) removal of a relatively small number of easily portable animals such as laying hens. Removal is also, ordinarily, carried out at night in order to avoid the risk of discovery and confrontation. The media and/or police will then be informed and no attempt will be made to conceal the identity of key activists. However, safety masks are sometimes worn (e.g. in laying sheds) and this does give opportunities for some identity concealment by some participants. We may, as a result, suspect that the authorities are given the identities of only a sample of activists and not everyone. There are also issues of concealment with regard to the broader networks of sympathizers who help to relocate and provide homes for rescued animals. Even so, open rescue does involve a strong element of genuine openness that covert rescue lacks. We might also struggle to associate the latter with Gandhian satyagraha, although this on its own need not rule out a classification of such action as civil disobedience given the demanding nature of Gandhian dissent. Indeed, there may be good reason for keeping the concepts of civil disobedience and satyagraha distinct in order to avoid a charge of excessive demandingness.

\section{Covert Action and the Animal Liberation Front}

At this point it may be worthwhile to focus upon one of the main reasons why it seems counter-intuitive to regard covert rescue as civil disobedience, i.e. organizational image, the way in which covert rescue has been deliberately presented by the network of agents who issue publicity under the ALF banner, publicity that is reminiscent of underground and quasi-terrorist organizations. To some extent, the ALF was the victim of bad timing. It emerged in the UK in the summer of 1976 at precisely the moment when growth of an organized revolutionary left (Trostkyists, Maoists, fragmentary groupings spun off from the declining communist parties of Western Europe) that had been significant around the time of the Vietnam War and the events of May 1968 in France, was going rapidly and permanently into reverse. Between 1975 and 1978 (give or take a few months), it seems to have become clear to many political activists that these groupings were not going to coalesce into mass organizations but would remain on the fringes of politics. ${ }^{6}$ Nonetheless, in the far broader left-wing political circles out of which the ALF grew, at first in Britain and then in America, a continuing aspiration for radical political change beyond anything conceived of by social democratic organizations, was combined with a lack of organizational impact. What

\footnotetext{
5 The Animal Enterprises Terrorism Act (2006) defines animal removal (i.e. rescue) as property damage, and contains the provision that terrorism includes 'Intentionally damaging or causing the loss of any real or personal property (including animals or records) used by an animal enterprise, or any real or personal property of a person or entity having a connection to, relationship with, or transactions with an animal enterprise'. For an assessment of the problems of this approach, see Hadley (2009).

6 For an unusually candid insider's view of the onset of crisis among the Trotskyist groupings in the midto-late 1970s see Harman (1979).
} 
helped to bridge the gap between aspirations and imagined political realities was a widespread idealization of a range of genuinely terrorist organizations such as the IRA, the PLO, the Popular Front for the Liberation of Palestine, the Red Brigades and the Baader-Meinhof Group. The legacy of this has, in more recent times, become extremely problematic for social democratic parties such as the Labour Party in England (the left wing of which has repeatedly been accused of antiSemitism). When the ALF was formed, left sympathies for paramilitary organizations were at their height.

The upshot is that while the ALF has always been formally opposed to violence, or at least opposed to violence against persons, it did initially model its public image upon terrorist groupings and, more specifically, paramilitaries. Balaclavas and combat fatigues, more familiar from artwork in West Belfast, have always figured prominently in ALF publicity photos. Rescued animals are held across the chest like assault rifles. And while this may have been a persuasive political image on the radicalized left in 1976, it is far less so for our own times. The ALF has, however, remained stuck with an image that was already out of step with political realities by the 1980s and that has become utterly untenable in the aftermath of the attacks of 9/11. Paradoxically, one reason why it has been so difficult for the ALF to change its mode of presentation is that it is not actually a centralistic terrorist organization. It does not operate under a violently enforced military discipline. More simply, and unlike bodies such as the IRA, nobody can give an authoritative order to change tack. The absence of a centralized command structure means that disputes about image and overall direction tend to rumble on without end. ${ }^{7}$ Given this, it is readily understandable why the open rescuers of the 1990s in Australia should have thought of open rescue as both radically different from the politically compromised activities of the ALF and as an alternative to the latter.

Even so, in addition to the absence of a critical mass of support for an extensive open rescue movement, there are at least two significant reasons why some animal rights activists continue to find covert rescue an attractive option, or at least a more attractive option than open rescue. Firstly, the open rescue model is largely inapplicable in the case of laboratory animals whose special predicament has always formed a lure for animal rights activists. ${ }^{8}$ The animals rescued in an open manner by ALV (and by other open-rescue operations such as Animal Liberation New South Wales) are typically deemed by their owners to have a low monetary value. Subsequent identification of rescued animals is also difficult. To the undiscerning eye of those who encounter thousands of birds every day, one low-priced chicken may look much like another. The upshot is that the recovery of animals is generally not attempted. Owners may want compensation or (an option we need not discount)

\footnotetext{
7 Perhaps the most prominent, and disastrous, example of a rare 'turn' by consensus was the alignment of the ALF with the Earth Liberation Front which sought, at the end of the 1990s to secure political change by economic attrition in the form of arson. Newkirk (2000, p. 336) has, with some plausibility, called this approach 'political suicide'.

${ }^{8}$ Marcus (2005) has questioned the strategic priority of focusing upon experimentation, but it does involve distinctive harms that can sometimes be absent from the food chain, Milligan (2010, pp. 126-132). Accordingly, there is at least one good ethical reason for according it a high level of attention.
} 
something close to payback or revenge. Or they may, more ambiguously, want something to be done. But they are not usually interested in the actual return of the rescued animals. By contrast, when lab animals are rescued from research facilities, they can represent several months of work and in the case of primates they may be expensive to acquire and difficult to replace. Individual lab animals are also, typically, tattooed for identification and this facilitates subsequent recovery. Even where efforts are made by rescuers to conceal tattooing, the presence of scarring and of any unusual injuries that have been inflicted upon an animal can also facilitate identification. From the rescuer's point of view, recovery can be a real concern. Sympathetic vets may have to be used by those who wish to prevent it from taking place. Because of this concern about recovery, covertness has a practical rationale that has nothing to do with the image and ethos of underground organization.

\section{Rethinking Civil Disobedience}

If we assume that civil disobedience is, by definition, action in defence of humans, then the differences between open and covert rescue will be beside the point. Neither will qualify. The reasons for making such a restrictive assumption are, however, bound up with the idea that civil disobedience is best understood in relation to something akin to contract theory. If our understanding of political arrangements is that something akin to a social contract exists among humans and that when the terms of the contract are violated a form of dissent that respects the regular relations between free and equal agents may be legitimate, we may be tempted to use this as the core of a theory of civil disobedience. Protest over matters that fall outside of contractual bonds between humans could still be reasonable, on such an approach, but they could not then count as civil disobedience. This is the kind of thinking that has long been associated with John Rawls although exactly how deeply it is embedded in his position is a matter of dispute. Rawls seems to exclude protest over non-human matters but he may be read more generously. ${ }^{9}$ Either way, the restriction has generally been rejected and I will take it that rejection is the best option. Certainly so, if we want to allow for at least some forms of ecoprotest to count as civil disobedience. And if we allow the latter, there is no good reason to deny that civil disobedience over animals is just as possible.

If we want to identify some core feature of claims about civil disobedience, and to root it more firmly in the tradition of Gandhi and Martin Luther King Jr, then we may do better to focus upon the idea of protest that has special standing. A more technical way of putting the same point would be to talk about the normativity of the concept of civil disobedience (various 'oughts' go with such talk). We may make sense of its normativity by pointing out that it is plausible to say that civil disobedience ought to have special legal standing (indeed some judicial figures believe that it already does, albeit at the level of background principles rather than explicit rules for sentencing) or that it has special moral standing (and hence it is

\footnotetext{
${ }^{9}$ Rowlands (1997, pp. 131-141), provides the classic defence of the applicability of Rawls to protest concerning non-humans. For an appraisal of Rowlands, see Garner (2013, pp. 32-38).
} 
due a certain kind of tolerant response), but the same is not true with regard to instances of direct action. The concept of direct action is normatively neutral. ${ }^{10}$

This idea of special standing can also be captured without appeal to problematic aspects of the familiar Rawlsian conceptual machinery associated with the account of civil disobedience in successive editions of A Theory of Justice. In particular, those aspects of the Rawlsian approach that would automatically rule out covert animal rescue as civil disobedience because such rescue does not look like a form of communication. The key notion that the influential Rawlsian account of civil disobedience is based upon is the idea of the illegally but peacefully communicated message: where legal protest over the relations between humans is not listened to, a way to make a point may need to be found beyond the bounds of the law. On such an account, the making of a point (in a particular way) is what really matters. ${ }^{11}$

The Rawlsian approach to these considerations is cited so often that it is easy to overlook its innovative nature and the fact that it has an awkward match-up with anything that we are likely to find in the writings of Tolstoy, Gandhi or Martin Luther King Jr. But what if the idea of civil disobedience as protest with a special standing were cashed out otherwise? For example, by appeal to a notion of civility. Such an approach could also claim a strong (perhaps stronger) precedent in Gandhi's writings and it need not automatically exclude all instances of covert animal rescue or (similarly) covert eco-protest. On the strongest version of Gandhi's account of civil disobedience, agents who engage in the latter are required to act out of a virtue of civility. ${ }^{12}$ More strictly, there is a doubling of Gandhi's discourse in which he refers to protest as an act of love while at the same time (and less demandingly) referring to it as action out of civility. ${ }^{13}$

Here, I will suggest (as Gandhi does seem to have recognized on other occasions) that while civility is less demanding than love, the requirement for an actual virtue of civility remains too strong if the relevant kind of action is to be available to ordinary flawed agents, to people like us, who have no special claim upon saintliness or exemplary virtue. ${ }^{14}$ If we hold otherwise we will face two difficulties: (1) the problem of defending the account of civility against a charge of elitism (a perennial problem for civility theory); and (2) the problem that an action which would otherwise be accepted as civil disobedience might not have this standing because of the character of the agents involved, as exhibited on other occasions. Rather than introduce a requirement that civilly disobedient action must express some underlying state of virtue, we can adopt Gandhi's less-demanding requirement that it must be in conformity with various minimal civil norms. What we will then have is an account of civil disobedience that is underpinned by a minimalist account of civility that escapes from the elitism problem and the agent-character problem. Yet,

\footnotetext{
${ }^{10}$ For an example of judicial recognition of the special standing of civil disobedience see Thornton et al. (2010, pp. 333-334).

11 Rawls (1971).

12 For the importance of the civility of civil disobedience see Gandhi (2007, p. 319; pp. 318-319) and Gandhi (1996, pp. 47-49, pp. 70-71).

13 Milligan (2014, pp. 291-295).

14 Milligan (2013, pp. 89-92).
} 
at long as the norms in question are sufficiently robust we need not have undermined the rationale for claiming that special standing still applies.

But it is one thing to suggest that such a minimalist account can be set up as a rival to a communication-based account, and quite another to actually set it out and to do so in a plausible manner. The latter task is somewhat too large a project for a single article. However, the outlines of such a civility-focused account can readily be given. Political action in line with the following norms will go some way towards capturing the relevant idea of 'special standing' protest.

(1) Respect for others or, if we have no fondness for the language of respect, the recognition that other humans are fellow humans i.e. members of the same moral community.

(2) The rejection of hate-speech. (Where communication is involved it too must be civil.)

(3) The avoidance of acts that are driven by hatred. (A more minimal commitment than the King/Gandhi/Tolstoy requirement that we love our enemies.)

(4) The largely successful commitment to try to avoid violence and threats of violence.

(5) The avoidance of cruelty, which has a special place in liberal discourse and a special connection to the idea of humanity. Acts will lose their special standing if they are cruel.

(6) The recognition of a duty of care or an avoidance of the reckless endangerment of others. (Although recklessness and its avoidance may turn out to be a matter of degree.)

There will, no doubt, be certain actions that superficially look like civil disobedience but fail to comply with the above minimal norms. Neo-Nazis blockading a synagogue as a celebration of the Holocaust, while singing 'We Shall Overcome', would not be engaging in civil disobedience for a plausible and nonarbitrary reason. While they might be non-violent and polite, theirs would be a false civility because their action would be inconsistent with (1) above. They would not be complying with a basic level of acceptance of all others (Jews included) as members of the same moral community. However, some instances of reactionary protest (however defined) might well qualify as civil disobedience. (Lawbreaking protest in support of hunting might qualify just so long as the protest does not itself take the form of hunting and the violence that it involves.) Gandhi would not have liked this inclusion of reactionary instances of civil disobedience, given that he saw civil disobedience as a branch of satyagraha, condisdered as the force of truth, but it is difficult to see how a civility-based account can be norm-based rather than virtuebased while avoiding this concession. Virtue requires a depth of insight that a basic level of civility does not. Moreover, from an activist standpoint, this inclusiveness has an obvious advantage: if various 'reactionary' instances of dissent are allowed to qualify then it may be harder for courts to deny the civilly disobedient standing of instances of dissent such as animal rescue (of whatever sort) on the basis that the cause in question is not just. 
A different sort of worry is that the proposed account will be too permissive or too inclusive. That it may not, in spite of being constraining up to a point, be sufficiently constraining. Against this, it may be pointed out that it will allow for the most plausible exclusions to be made even in cases where there seems to be some sort of good cause. For example, while non-violent but disruptive eco-actions might qualify, many other eco-actions will not do so. ${ }^{15}$ Covertly putting spikes into trees as a way to disrupt felling might not itself be violent but it would involve reckless endangerment and so would conflict with (6) above. However, what is noticeable in the present context is that this failure to qualify has nothing to do with the covertness of such 'tree spiking'. Other eco-actions, such as shifting boundary markers on sites scheduled for destruction, might well qualify while remaining equally covert. Similarly, there are instances of covert animal rescue that will fail to qualify for some or other reason. The scrawling of threats of violence upon lab walls by animal rescuers, would fail to do so and might undermine any claim of civil disobedience for the associated rescue. Even if civil disobedience does not need to be thought of primarily as a form of communication, when communication is involved it cannot take the form of threats while at the same time retaining a plausible claim to be civil. For this reason, it seems clear that many and perhaps most (and possibly all) actual instances of actual covert rescue by the ALF do not qualify, but this is not simply because of their covertness but because of their failure to comply with norms of civility.

There may also be other kinds of animal rescue which would, hypothetically, fail to qualify irrespective of whether the rescue of animals was open or covert. For example, the rescuing of animals from any laboratory engaged in work with an exceptionally dangerous virus could well involve reckless endangerment (although such a situation has not, as yet, been confirmed). And any form of animal rescue that endangered the lives of the animals themselves would also fail to qualify.

The key point here is that while plausible exclusions may be made, and imitations of civil disobedience may be ruled out, nothing in the above cluster of basic civil norms will automatically exclude all possible instances of covert animal rescue. And so, while covert rescue may lack the political potential of open rescue it could also, in some instances, count as civil disobedience depending upon the manner in which it is carried out. Or rather, it may do so just as long as a shift is made from a communication-based account of civil disobedience to a more civilityfocused account of the above sort.

\section{Reasons Why Civil Disobedience is not Supposed to be Covert}

Given that there is a special rationale for covert rescue, particularly where lab animals are concerned, open and covert rescue (or at least some radically modified version of the latter) may begin to look like complementary activities. And, to some extent, this is not an entirely misleading impression. However, beyond both being instances of rescue, they still do not look like the same sorts of activities. While

15 Martin (1990, pp. 291-310). 
there is no obvious and good barrier to regarding open rescue as civil disobedience, it may still seem intuitively obvious that covert rescue simply cannot qualify, irrespective of how it is carried out. Its sheer covertness may seem to be an insurmountable obstacle. And one reason for this is that civil disobedience has typically been regarded (at least in the literature of the past couple of decades) as public and, even more strongly, necessarily public. Again, the Rawlsian account has set the tone for a good deal of writing on this theme. For Rawls, 'civil disobedience is a public act. Not only is it addressed to public principles, it is done in public. It is engaged in openly with fair notice'; similarly, it is 'a public, conscientious yet political act contrary to law'. ${ }^{16}$ But exactly why this must be the case is not altogether clear. The Civil Rights Movement and successive campaigns for Indian independence were public but they were also religiously inspired and guided by a sense of spiritual values. Yet we do not consider the latter to be essential to civil disobedience. (Although Gandhi's commitment to regarding civil disobedience as a branch of satyagraha seems at times to entail precisely this.) Moreover, none of the more obvious reasons for insisting upon the restriction to public acts look simultaneously strong and sufficiently fine-grained to exclude covert rescue without also excluding non-controversial instances of civil disobedience. The reasons for exclusion, if they prove anything, seem to prove too much. Let us consider the more obvious reasons in turn.

(1) Reason-1 Civil disobedience cannot take the form of action which is intrinsically suspect, and there is always something intrinsically suspect about covertness.

The idea that covertness is automatically suspect has quite a pedigree. It goes back at least as far as Pericles and his account of why the Athenian state preferred to operate out in the open. Understood as a requirement for civil disobedience, it can be found in both Gandhi's writings and in Hugo Bedau's account of civil disobedience, written at the time of the Civil Rights Movement, in the early 1960s. For Gandhi, 'Disobedience to be civil has to be open and non-violent'. ${ }^{17}$ (Although, here again, what is doing the real work may seem to be a notion of civility with the idea of openness regarded as a subordinate feature of the latter.) For Bedau, 'Any one commits an act of civil disobedience if and only if he acts illegally, publicly, non-violently, and conscientiously with the intent to frustrate (one of) the laws, policies, or decisions of his government'. ${ }^{18}$ But while there is something attractive about this option it does, nonetheless, seem to rest upon an over-generalization. Covertness, at least in the form of identity concealment, can be sinister but it need not be so. There is, for example, nothing particularly suspect about the actions of the street artist Banksy, yet he acts in a covert manner, with his identity (until recently) concealed, partly as a rejection of celebrity culture. ${ }^{19}$ A comparable point may be

\footnotetext{
16 Rawls (1971, p. 364).

17 Gandhi (2007, p. 319).

18 Bedau (1961, p. 661).

19 Banksy (2005). And see Elsworth-Jones (2012, pp. 97-98) on reasons for his anonymity.
} 
made about those who wore V-masks at Occupy Movement sites during the popular 'Occupy' protests of 2011. (Masks with the face of a Guy Fawkes-type character, which were referred to by one journalist as a 'symbol of festive citizenship'.) ${ }^{20}$ Identity concealment was bound up with the carnivalesque component of the protest, with a sense of losing oneself and with a rejection of charismatic leadership that was symbolized by protestors presenting themselves as part of the anonymous mass or 'the $99 \%$ '. ${ }^{21}$ Similarly, there is a long-standing, but somewhat rare, practice of identity concealment that we might call 'Jane Doe refusal'. This involves a refusal to disclose identity following arrest in order to continue to disrupt the legal process, even at the expense of being incarcerated rather than bailed. Instances of Jane Doe refusal can be found in accounts of both the anti-abortion movement of the 1980 s and the anti-capitalist movement of the early 2000 s. $^{22}$

Against the idea that covertness is intrinsically suspect there is a case for saying that whether or not acting in a covert manner is sinister, suspect or both, depends at least in part upon the reasons for the covertness, its impact upon others and the lengths to which agents will go in order to preserve it. Thought of in these terms, there need be nothing intrinsically suspect about the reasons for covertness by animal rescuers of either sort. A degree of covertness by both open and covert rescuers at the point of rescue may readily be explained by appeal to a desire to avoid any violent physical confrontation with security personnel. The continuing refusal of more strictly covert ALF rescuers to disclose their identities after a rescue may also be explained, at least in part, by a desire to minimize the (all-too genuine) risks of animal recovery. Neither of these motives seem at all sinister, and both are at least consistent with a refusal to protect anonymity by violence or by threats rather than guile. However, a reformulation of the objection might be run by drawing from the idea of an avoidance of face-to-face confrontation (violent or otherwise). Perhaps there is something ethically privileged in the facial encounter. This is a familiar idea which appears in a figurative form in the writings of Emannuel Levinas but which can be found in a more literal and literary form in Iris Murdoch and indeed Herman Melville. Within radical political theory, it occurs as a reason for favouring the classic New England Town Hall Meeting over the anonymity of referenda. ${ }^{23}$ But a good deal of what seems to be non-controversially civil disobedience (including open rescue) does not involve confrontation of this face-to-face sort. A civilly disobedient crowd can be, in a sense, faceless i.e. an anonymous mass. Added to which, police personnel can also have their faces concealed behind masks, a move that may rule out any direct, two-way facial encounter. If such an encounter, or even something rather more one-sided, were

\footnotetext{
20 Jones (2011).

21 Van Gelder (2011, vii, p. 1).

22 For Jane Doe refusal by anti-abortionists, see Nathanson (1989, pp. 31-32); for Jane Doe refusal by anti-capitalists, see Thompson (2010, pp. 59-60).

23 Levinas (1985), pp. 95-98. Murdoch (1957) centres its narrative around the facial encounter. Bryan (2004, p. 16) favours the town hall meeting over referenda because of the latter's lack of face-to-face engagement. For the latter, see also Milligan (2016, pp. 100-101).
} 
required for civil disobedience then we are likely to exclude a great deal of entirely open and peaceful activity.

(2) Reason-2 It may be suggested that civil disobedients are protestors who accept the consequences of their actions and this requires that they must act publicly and must disclose their identities. ${ }^{24}$

In the case of covert rescue it may be charged that identity concealment is not motivated solely by reflection upon the interests of the rescued animals but by a refusal to stand up and be counted. However, this line of criticism is problematic. Covert rescue no doubt involves all sorts of people engaging on a once-only basis, but it depends upon a cadre of experienced activists who are well aware that sooner or later they are liable to be arrested. Keith Mann's insider account of the ALF, From Dusk 'til Dawn (2009) is a testament to this fact. It is, in part, a history of arrests and imprisonments, largely written while Mann was in jail. ${ }^{25}$ Ingrid Newkirk's somewhat earlier narrative account of the making of an ALF activist, Free the Animals (1992, revised in 2000), although a little dated and dramatized, contains an account of an introductory skills camp where lower-level activists are warned about the strong likelihood of both arrest and imprisonment: "We're not building flash-in-the-pan heroes here," M continued, "but a long-term army of committed people who accept that they may end up in the clink. Don't think for one moment that you're too smart to be caught." ${ }^{26}$ Even with the (problematic) appeal to the military imagery of army-building (an appeal which, curiously, does match up with recurring Gandhian imagery of a war for justice) given recognition of this sort, that arrest is more a matter of when rather than if, it is not at all obvious that overt and covert rescue really do differ in term of the readiness of activists to accept arrest as the price of their dissent. It is perhaps more accurate to say that open rescue has an association with regarding arrest as itself a useful political act. At least sometimes, open rescue can involve an invitation to arrest, an offering of oneself as a sacrifice. But it is not obvious that civil disobedients must act in such a way. It may better capture the outlook and practice of the leaders of civil disobedience movements (such as King and Gandhi) rather than the approach of ordinary participants who are more or less prepared for arrest but who do not characteristically invite it.

(3) Reason-3 Civil disobedience is primarily a form of address, a form of communication which is, by its nature, a public act.

What this leaves us with is precisely what we may draw from Rawls, i.e. a theory of communicative political practice-what I have referred to elsewhere as the

\footnotetext{
${ }^{24}$ Foreman (1991, pp. 130-131) uses this as a way to distinguish between low-level eco-sabotage, i.e. 'monkeywrenching' and civil disobedience in the tradition of Gandhi, the Civil Rights Movement and the peace movement. According to Foreman, only civil disobedience requires that credit be taken for the action while monkeywrenching is simply more effective if practised covertly.

25 Mann (2009, pp. 16-19).

26 Newkirk (2000, p. 50).
} 
'communication thesis' ${ }^{27}$ On such a view, civil disobedience is a way of saying something and, where the cause is just, it may be warranted when other, legally sanctioned and less disruptive, opportunities for communicating effectively and in a timely manner, have been cut off. ${ }^{28}$ However, as a cautionary note about endorsing the communication thesis too readily, it may be pointed out that its provenance is somewhat ad hoc, and its justification is open to question.

With regard to provenance, the thesis goes back to both Rawls and, with qualification, to Carl Cohen, but there is no explicit requirement for communication in the single most influential academic account of civil disobedience to have been set down prior to Cohen and Rawls, i.e. the Civil Rights Movement account advanced by Hugo Bedau in the early 1960s and referred to above. Nor is it consistently present in the writings of Thoreau, Tolstoy, Gandhi or King, although there are intermittent hints at something of this sort. The reason for this is simple. Cohen and Rawls encountered a movement that had to rely upon indirect means of protest because what it was protesting about (the Vietnam War) took place elsewhere. Justifying indirect action, such as the disruption of traffic, as something other than juvenile and irrelevant to the issue in question, required appeal to the communicative role of such protest. However, this always meant that the driver for this conception of civil disobedience was the modelling of indirect rather than direct forms of dissent whose communicative standing has always been at least ambiguous.

What there is, by way of earlier precedent for the resulting conception of civil disobedience, is a commitment on the part of Thoreau to regard civil disobedience as conscientious action, a commitment on the part of Tolstoy to regard it as a conscientious act of love, and an extension of this view by Gandhi and King that turns civil disobedience into a loving appeal to the conscience of the political opponent. It is, however, a problematic extension because it does not obviously match up particularly well with the actual practice of either the US Civil Rights Movement or the movement for Indian independence. Nonetheless, the idea of a loving appeal provides us with a view of civil disobedience that arguably presupposes communication of a sort, even if it does not explicitly call upon the latter. However, it also (again, worryingly) requires us to regard civil disobedience as a special kind of spiritual practice rather than merely allowing us to do so in particular cases. As such it is a rather awkward precedent for those who wish to depart from Tolstoy, Gandhi and King by presenting a strictly secular theory of civil disobedience (and this is precisely what advocates of the communication thesis, from John Rawls through to Jürgen Habermas have striven to do). ${ }^{29}$ However, if some stronger precedent for a restrictive, communicative, understanding of civil disobedience could be found, such a precedent alone still might not be enough to

\footnotetext{
27 For the communication thesis see Milligan (2013, pp. 18-21).

28 The temporal clause is included in order to allow for cases where a threatened harm will not be forestalled by the available opportunities for discourse. A similar point is made about direct action, in the environmental case, by Humphrey (2006).

29 Habermas (1985). For both Rawls and Habermas, while agents might appeal to religious principles in order to justify civil disobedience, such claims must permit translation into the shared language of what the latter refers to as 'the public sphere'. For the significance of the latter in this context see Smith (2011).
} 
warrant our continuing to regard civil disobedience in this way. And to say this is to acknowledge that there never has been a single, stable and unchanging concept of civil disobedience, but rather a concept which has been modified over time. It should, however, be noted that such modification is entirely in line with a Gandhian attitude towards conceptual innovation. It is an important part of his understanding of what political theory does. ${ }^{30}$ Some level of semantic drift/conceptual innovation also helps to explain the problematic nature of matching up any necessary and sufficient conditions account with historical exemplars. ${ }^{31}$

With regard to the justification of particular reworkings of the concept, on a Rawlsian account it is the communicative standing of civil disobedience that allows us to understand why it has to be non-violent. Violence cuts across communication and so, insofar as the action is genuinely communicative it will also have to be nonviolent. However, this move involves a false generalization and is, in any case redundant. It involves a false generalization because violence can be communicative, and communicative in more than the loose sense in which all actions may be said to communicate something. Violence often sends a message. (I say this only as a point about violence and not at all as a justification of it.) The move is, additionally, redundant because the centrality of non-violence to our understanding of civil disobedience does not need to be underpinned by appeal to something which is far more open to dispute. ${ }^{32}$ In some respects, it actually obscures the centrality of non-violence by making it seem like a derivative feature.

\section{Challenging the Communication Thesis}

In the light of this third reason for requiring that civil disobedience must be public, those who wish to defend the possibility that covert rescue could be civil disobedience (even though it often, perhaps even always, fails to qualify) have two options: firstly, an argument may be made that some instances of covert rescue could be sufficiently communicative to qualify; and secondly, the communication thesis may itself be challenged. Both options have something going for them. It can, for example, be argued that covert rescue genuinely is communicative, albeit only up to a point. In the case of the rescue of lab animals, it does (deliberately) send a message to practitioners of experimentation that their actions are deemed indefensible by the rescuing agents (or whichever constituency they believe themselves to represent). And when it is accompanied by subsequent publicity it

\footnotetext{
30 Milligan (2014, p. 288) summarizes the attitude towards conceptual modification in Gandhi's commentary on the Baghavad Gita.

31 The line between conceptual change and the development of a concept may be hard to draw. But all that I am seeking to presuppose by speaking of the latter rather than the former is an element of strong continuity between successive construals of 'civil disobedience'.

32 This is not, however, to endorse an absolute exclusion of everything that might be construed as violence. Gandhi, in his commentary upon the Gita claims that breathing and thinking involve violence. When his political writings uphold non-violence it is not absolute non-violence that he has in mind (Gandhi 2011, p. 266, p. 309). Carl Cohen was, again, more cautious than Rawls about this matter and suggested that it was 'arbitrary' to entirely rule out violence of every sort in every context (Cohen 1971, pp. 22-36).
} 
sends a message to the experimentation establishment as a whole that their most publicity-sensitive practices may be exposed to public view. Given this, what may be required for a comprehensive exclusion of civil disobedience claims is some stronger version of the communication thesis such that civil disobedience is not just action with a communicative dimension but is essentially or primarily communicative action. One way to make this shift would be to say that the primary intention of the agents involved has to be the communication of a message. This would, admittedly, count against a good deal of covert rescue. While rescues are sometimes filmed, it would be odd for a rescue, in full flow, to be called off because a camera had ceased to function.

No doubt it is hard to disentangle the multiple intentions of agents. There is ambiguity and indeterminacy in what any of us may be trying to accomplish at any given point in time. Even so, there does seem to be at least some sense in which the immediate and primary aim of covert rescue tends to be the rescue of the animals themselves. However, even in the face of such a strongly formulated version of the communication thesis it may still be pointed out that at least some rescues, and particularly some of the earliest ALF actions if not later actions, may well have been carried out with something close to a primarily communicative intent, as a signal that the ALF was alive and thriving. In spite of covertness, such rescues would still seem to qualify as communicative acts and hence would still be candidates for civil disobedience in spite of their covert dimensions. To absolutely guarantee their exclusion, recourse might have to be made to a simpliciter insistence upon publicness on its own or in conjunction with an appeal to communication; or else there might be a return to the anthropocentric exclusion of all actions other than those which concern basic issues of inter-human justice; or, alternatively, an even more stringent and perhaps less attractive version of the communication thesis may be required. None of these look like particularly promising options.

If the communication thesis is construed in a sufficiently open manner it may be unobjectionable but will not exclude covert rescue. If it is construed strictly, the second option, of challenging the thesis, may then be the best response. As part of a softening-up exercise prior to its rejection, it may be pointed out that, like the anthropocentric restriction of civil disobedience to actions that defend human liberties, it may simply exclude too much. Public actions that do not involve any form of identity concealment, but which are ways of frustrating, obstructing or preventing, will also be ruled out, unless they too are regarded as, simultaneously, ways of communicating (on a strong account, primarily forms of communication). Eco-actions such as the blockading of roads, the occupation of endangered woodland sites and instances of 'locking-on' by activists who chain themselves in situ in order to cause non-violent inconvenience, will all fail to qualify. We may, of course, attempt to play up their communicative dimension, but this could distort our understanding of activist intent. Nonetheless, these do look suspiciously like precisely the sorts of actions that we would ordinarily regard as civil disobedience unless we happen to regard the latter concept as out of date.

What is, perhaps, curious here is that while many other features of the Rawlsian account have steadily been chipped away over time, the communication thesis has continued to be accepted with relatively few dissenting voices. The most notable of 
the latter has come from Jennifer Welchman. ${ }^{33}$ In the light of the rise of the ecology and animal rights movements, and against the backdrop of anti-capitalist protests over debt and world trade, Welchman mounted a brief but frequently cited attack which was based around three claims: (a) the communication thesis was little more than an ad hoc response to vocal opponents of civil disobedience, a way of placating hostile critics rather than generalizing upon the experience of protesters; (b) it excludes, for no sufficiently good reason, at least one previously accepted paradigm instance of civil disobedience: the Underground Railroad in the antebellum South; and (c) it requires an arbitrary prioritization of indirect protest (which is essentially communicative) over instances of direct action.

As a rider, Welchman conceded a level of consistency to Rawls that was absent from Cohen. While Rawls was comparatively open about the normative and revisionary nature of his account (i.e. its status as an account of what we ought to think of as civil disobedience), Cohen was far more cautious. He recognized, from the outset, and was uncomfortable with the fact that the communication thesis did create problems for the long-standing classification of slave rescue by Underground Railroad activists as civil disobedience. (Biographies of Harriet Tubman still use this classification as a way of drawing a connection between her activities and the Civil Rights Movement.) ${ }^{34}$ Unwilling to entirely abandon this paradigm case, Cohen retained it as a marginal instance, thereby ruling out the stricter account of the communication thesis towards which Rawls inclined. But if this move were to be endorsed, it would be all but impossible to exclude every possible instance of covert animal rescue unless the (normally rejected) anthropocentric restriction is reinstated. ${ }^{35}$ If the Underground Railroad was a marginal case of civil disobedience then some non-violent and suitably structured instances of covert animal rescue may also be instances of civil disobedience.

More generally, while the Rawls/Cohen appeal to communication was, as Welchman accepted, a good way to make sense of indirect civil disobedience, it was and is far from obvious that our understanding of civil disobedience as a whole ought to be modelled upon the latter. Why not, for example, embrace a disjunctive account such that civil disobedience can be either a certain kind of communication or a certain kind of direct action in which communication plays (at most) a subordinate role? Such an account might at least have the merit of a good fit with all of the paradigm historical instances that are partly constitutive of our understanding of the concept. While CND and the Vietnam protests involved indirect action, the Civil Rights Movement primarily involved what King openly referred to as direct action (not lovingly addressed to the conscience of the opponent but aimed instead at embarrassing the Federal Government into enforcing its laws). Finally, the Indian independence movement involved both indirect protest (e.g. non-cooperation with the state educational system) as well as direct action (e.g. the violation of the

\footnotetext{
33 Welchman (2001).

34 Clinton (2005, p. 56).

35 The relevance of this example to the covert rescue of animals, need not be made contingent upon the quite different claim, associated with the 'liberationist' tradition of animal rights, that the standing of animals today is strongly analogous to that of slaves. For the latter, compare Francione (2008, pp. 46-53) with Tuan (1984) which stresses the more ambivalent position of animals as property.
} 
restriction upon private individuals producing and selling salt). A disjunctive approach to the concept looks promising.

Its attractiveness may lead us to wonder why the communication thesis, modelled as it was upon indirect dissent, ever became quite so embedded. But here we may reflect not only upon a narrative about the moment at which Rawls and Cohen were writing, but also upon the deliberative turn in political theory which was already gaining momentum in the 1970s. If democracy was not just about procedures, but about effective and informed communication, then why not regard civil disobedience in much the same light? However, as it fits so well with such a respectable trend in political theory we may then wonder whether the price of sticking with the communication thesis in spite of its problematic features is particularly high? After all, every theory will have its problems. I will suggest that the price is too high because the retention of the thesis risks turning civil disobedience into an endangered concept. More specifically, it leaves civil disobedience vulnerable to what we may call the 'argument from below', i.e. the argument that civil disobedience is overly deferential to authority and aims to persuade political elites who stand in need of coercion rather than persuasion, and therefore activists ought to be in the direct action business rather than the civil disobedience business. Variant formulations of this argument have gained widespread currency among a variety of political activists, such as environmental activists (Dave Forman advanced it during his Earth First! days); animal rights activists (Paul Watson of the Sea Shepherds has appealed to version of it); and the activists involved in the Occupy Movement of 2011. ${ }^{36}$

One of the reasons why such an abandonment (or at least partial abandonment) of the concept is problematic is that no other concept carries the moral authority of 'civil disobedience', and none is likely to do so for the foreseeable future. We may speak of 'direct action' (as Martin Luther King and the anarchist tradition both do) or of 'radical disobedience' (and similar concepts that have emerged among ecoactivists). However, none of these concepts is so deeply embedded in traditions of dissent in which the manner of the protest is, from an ethical standpoint, exemplary in ways that call for special consideration. And this, rather than an attitude towards animal activism alone, is the driving consideration behind the present paper: the concept of civil disobedience is, at present, irreplaceable yet the ways in which the theory of civil disobedience has been shaped by presumptions about communication and overtness, drive it apart from actual instances of non-violent dissent whose goals may be varied and often concerned with the prevention rather than the publicizing of harms. What is then in danger of being lost is the ongoing relevance of a concept of protest that still has a great deal of work left to do.

Open Access This article is distributed under the terms of the Creative Commons Attribution 4.0 International License (http://creativecommons.org/licenses/by/4.0/), which permits unrestricted use, distribution, and reproduction in any medium, provided you give appropriate credit to the original

\footnotetext{
36 For reticence about advancing a claim of civil disobedience in relation to the Occupy Movement, see Harcourt (2011). For Paul Watson advancing the argument from below see Milligan (2013, pp. 27-28). For Dave Foreman advancing this position, see Foreman (1991, pp. 130-131).
} 
author(s) and the source, provide a link to the Creative Commons license, and indicate if changes were made.

\section{References}

Banksy, 2005. Wall and peace. London: Century.

Bedau, Hugo A. 1961. On civil disobedience. The Journal of Philosophy 58 (21): 653-665.

Bryan, Frank. 2004. Real democracy: The New England town hall meeting and how it works. Chicago, IL: Chicago University Press.

Clinton, C. 2005. Harriet Tubman: The road to freedom. New York and Boston: Black Bay Books.

Cohen, Carl. 1971. Civil disobedience: Conscience, tactics, and the law. New York, NY: Columbia University Press.

Elsworth-Jones, Will. 2012. Banksy: The man behind the wall. London: Aurum Press.

Foreman, Dave. 1991. Confessions of an eco-warrior. New York, NY: Crown Trade.

Francione, Gary L. 2008. Animals as persons: Essays on the abolition of animal exploitation. New York, NY: Columbia University Press.

Gandhi, Mohandas K. 2007. An autobiography: The story of my experiments with truth, Mahadev Desai, trans. London: Penguin.

Gandhi, Mohandas K. 2011. The Bhagavad Gita according to Gandhi. New Delhi: Orient Publishing.

Gandhi, Mohandas K. 1996. In Selected political writings ed. Denis Dalton. Indianapolis, IN: Hackett Publishing Company Inc

Garner, Robert. 2013. A theory of justice for animals. Oxford: University Press.

Habermas, Jürgen. 1985. Civil disobedience: Litmus test for the democratic constitutional state. Berkeley Journal of Sociology 30: 95-116.

Hadley, John. 2009. Animal rights extremism and the terrorism question. Journal of Social Philosophy 40 (3): 363-378.

Harcourt, Bernard. 2011. Occupy wall street's “political disobedience," New York Times online, 13 Nov 2011. http://opinionator.blogs.nytimes.com/2011/10/13/occupy-wall-streets-political-disobedience/ ?_r=0. Accessed 13 July 2015.

Harman, Chris. 1979. The crisis of the European revolutionary left. International Socialism 2 (4): 49-87.

Hawthorn, Mark. 2010. Striking at the roots: A practical guide to animal activism. Winchester and Washington: O-Books.

Humphrey, Matthew. 2006. Democratic legitimacy, public justification and environmental direct action. Political Studies 54: 2.

Jones, Jonathan. 2011. Occupy's V for Vendetta protest mask is a symbol of festive citizenship. The Guardian 04 Nov 2011, http://www.guardian.co.uk/commentisfree/2011/nov/04/occupy-movementguy-fawkes-mask. Accessed on 13 July 2015.

Levinas, Emmanuel. 1985. Ethics and infinity: Conversations with Philippe Nemo. Trans. Richard A. Cohen. Pittsburgh, PA: Duquesne University Press.

Mann, Keith. 2009. From dusk 'til dawn: An insider's view of the growth of the Animal Liberation Movement. Location: Voice of the Voiceless Communications.

Marcus, Erik. 2005. Meat market: Animals, ethics, and money. Boston, MA: Brio.

Mark, Patty. 2003. Opening doors and eyes to animal suffering. The Abolitionist interview with Patty Mark. The Abolitionist, 15.

Martin, Michael. 1990. Ecosabotage and civil disobedience. Environmental Ethics 12 (4): 291-310.

Milligan, Tony. 2016. The next democracy: The possibility of popular control. London: Rowman and Littlefield.

Milligan, Tony. 2017. Gandhian Satyagraha and open animal rescue. In Ethical and political approaches towards nonhuman animal issues, ed. Gabriel Garmendia, and Andrew Woodhall. Harmondsworth: Palgrave Macmillan.

Milligan, Tony. 2014. Civility and politicized love in Gandhi. Religions of South Asia 8 (3): 285-300.

Milligan, 2013. Civil disobedience: Protest, justification and the law. London and New York: Bloomsbury.

Murdoch, Iris. 1957. The sandcastle. London: Chatto and Windus.

Naess, Arne. 1974. Gandhi and group conflict. Oslo: Universiteitsforlaget. 
Nathanson, Bernard. 1989. Operation rescue: Domestic terrorism of legitimate civil rights protest? Hastings Centre Report 19: 31-32.

Newkirk, Ingrid. 2000. Free the animals: The amazing true story of the Animal Liberation Front. New York, NY: Lantern.

O’Sullivan, Siobhan. 2011. Animals, equality and democracy. Basingstoke: Palgrave Macmillan.

Rawls, John. 1971. A theory of justice. Cambridge, MA: Harvard University Press.

Rowlands, Mark. 1997. Contractarianism and animal rights. Journal of Applied Philosophy 14 (3): 235-247.

Sarah, Van Gelder. 2011. This changes everything: Occupy wall street and the 99\% movement. San Francisco, CA: Berrett Koehler.

Smith, William. 2011. Civil disobedience and the public sphere. The Journal of Political Philosophy 19 (2): $145-166$.

Thompson, A. K. 2010. Black bloc. White Riot: AK Press.

Thornton, P., R. Brander, R. Thomas, D. Rhodes, M. Schwarz, and E. Rees. 2010. The law of public order and protest. Oxford: Oxford University Press.

Tuan, Yi-Fu. 1984. Dominance and affection. New Haven, CT: Yale University Press.

Welchman, Jennifer. 2001. Is ecosabotage civil disobedience? Philosophy and Geography 4: 1. 